\title{
СЛОВО ЯК ІНДИКАТОР КОМУНІКУВАННЯ У ДУХОВНОМУ ДІАЛОЗІ: ДЕОНТОЛОГІЧНИЙ АСПЕКТ
}

\author{
Тетяна Хоменко \\ Львівський національний університет імені Івана Франка \\ вул. Генерала Чупринки, 49, 79044, Львів, Україна \\ e-mail: homenko.tet@gmail.com \\ https://orcid.org/0000-0003-2917-3469
}

У статті порушено проблему смислової підміни вартості слова як домінанти культуротворення, якісного комунікування, смислотворення та потужної інтелектуальної одиниці світоглядної парадигми мислення. Зокрема, зауважено, що сучасний інформаційний простір переважно зорієнтований виключно на новинний «порядок денний», за яким, з одного боку, інформація сьогодні на сьогодні; з іншого - принцип «only bad news are good news», а деонтологічний принцип обов'язку відповідальності за слово і діалогомісткість софійного слова просто ігноруються. Авторка доводить, що про якість комунікування в суспільстві можемо розмірковувати з огляду на слово, яке завдяки своєму семантичному навантаженню $є$ індикатором якості комунікування і духовної зрілості суспільства.

Ключові слова: слово, духовність, духовні вартості, духовний діалог, якісне комунікування, спілкування, обов’язок відповідальності.

Постановка проблеми. В епоху XXI століття людство як субстанціальна маса ідей та інтелекту конгломерується з епохою панування холодного розуму, приладів та апаратів, а людина як суб’єкт і об’єкт інформаційно-технологічного простору втрачає спорідненість із метафізичною сферою своєї екзистенції і здатність по-новому інтерпретувати світ. Для неї життя перетворилося на комплекс незмінних імперативів та непорушних ідеологічних догм, що позбавляє людину здатності до креативного опанування даності світу і відкриває простір для маніпулювання самою людиною як даністю, що позбавлена здатності критичного світосприйняття, самостійного аналізу і прийняття рішень. Одвічні етичні норми та моральні установки також випадають 3 поля зору звичайного обивателя.

Моральна деградація чимраз більше вражає ще здорову частину соціуму.

Чимало засобів масової інформації високу місію - стояти на сторожі слова - також потрактовують з позицій моральної деградації, а проте, майстерно завуальовують це оманливими щирістю та правдоборством (що особливо уявнилося в процесі нинішніх президентських перегонів). Занадто помітними стали смислові підміни,

(C) Хоменко Т., 2020 
що, власне, й вказує на потребу протидії сучасним інформаційним і пропагандистським технологіям.

Для того, щоб не виник бар'єр між сучасним реципієнтом та зовнішніми чинниками, які спекулюють свідомістю, консенсусу можна досягнути лише послуговуючись моральним підгрунтям, особистим внутрішнім завданням та ідеєю комунікації, базовим субстратом якої є мова. Від початку історії людства мова стала основним чинником, що відрізнив homo від animalis. Однак зараз спілкування, навіть на мовленнєвому рівні, доволі часто супроводжується відчуттям загнаності в глухий кут. Тому на перший план виходить проблема мови християнського тексту в світоглядній публіцистиці, оскільки вона виступає медіатором між зовнішнім світом та внутрішньо-суб'єктивним світом людини.

Адже саме через моральну деградацію суспільства, мова втратила свою основну здатність - впливати на світогляд реципієнтів - і потребує додаткових стимулів для регенерації свого первісного призначення - удосконалення духовності людства, що може пояснити потребу актуалізації і активації деонтологічних засад в інформаційному і комунікативному полі сучасності.

Аналіз останніх досліджень та публікацій.

Схожі питання у своїх наукових роботах досліджували такі українські і зарубіжні вчені: С. Аверінцев, М. Бахтін, М. Бубер, В. Буряк, С. Вовканич, Г.-Г. Гадамер, Я. Дашкевич, М. Зубрицька, С. Кримський, Й. Лось, В. Малахов, М. Маринович, І. Ортинський, Дж. Д. Пітерс, Б. Потятиник, Й. Рацінгер, В. Різун, С. Сверстюк, О. Федик, Т.-Л. Фрідман та ін. Зокрема, тему діалогу в сенсі морально-етичного дозрівання людини, порушено у працях С. Аверінцева, М. Бахтіна; М. Бубер розглядав формування діалогічних векторів у тріаді світ-людина-Бог; Дж. Д. Пітерс зосередив увагу на діалогічних моделях «розсіювання» слова, О. Федик дослідила слово як духовний адекват світу (дійсності); напругу смислового поля XXI сторіччя і роль слова як архетипу духовного життя людини спостеріг С. Кримський; про обов'язкове перебування у слові розмірковував свого часу Г.-Г. Гадамер; про діалогічну природу людини в пастирському ключі говорив також, і неодноразово, Іван Павло II. Майже кожен з названих авторів також аналізував біблійні тексти.

Мета роботи: дослідити потенціал слова як якісного індикатора комунікативного процесу, спрямованого на діалогічне формування морального типу мислення в сучасному духовному дискурсі, яким є не лише спілкування на релігійну тематику, але передовсім комунікування на рівні високих моральних принципів

\section{Завдання:}

- осмислити історичні тенденції комунікаційних чинників 3 проекцією на сучасний медійний простір.

• з'ясувати суть поняття «духовний діалог» в контексті процесів комунікування сучасності.

- вивчити феномен змістотворення на принципах деонтичності; Методологічна основа дослідження.

У дослідженні основними стали порівняльно-історичний метод - для з'ясування взаємовпливу різночасового, але багато в чому спільного, трактування слова в контексті діалогічної його природи. Також на основі опрацювання відповідної літератури застосовано методи: історичних аналогій та узагальнень, абстрагування та аналізу. 
Виклад основного матеріалу дослідження. Американський журналіст Тhe New York Times i 3-разовий лауреат Пулітцерівської премії Томас Л. Фрідман у своїй знаменитій книзі «Світ плаский», окрім того, що зауважив сплощення світу через широкі можливості Інтернету, що призвело водночас і до спрощення комунікування, в одному з розділів робить висновок про те, що сьогодні ми переживаємо «епоху переривання»: «Ми прийшли від залізної доби до доби промислової, потім до інформаційної доби і нарешті увійшли в добу переривання. Сьогодні ми постійно перериваємо одне одного (і самих себе) усіма цими миттєвими повідомленнями, електронними листами та дзвінками на мобільний телефон [...]. Хіба можна думати і творити в таких умовах? [...] Дехто вже висловлює побоювання, чи не спричинить епоха переривання занепаду цивілізації, бо обсяги уваги та зосередження катастрофічно меншають і в геть усіх можна буде діагностувати розлад та дефіцит уваги» ${ }^{1}$ А за таких умов, звісно, годі й говорити про якість комунікування. Адже розсіяна увага - це передовсім втрата важливих смислових ланок у ланцюгу логічних зв’язків i перетворень. Звідси і фрагментарність знань, і спростачення мови, і бідність уяви, i втрата здатності до креативного освоєння інформації світу загалом, оскільки інформація лише задля інформації , інформування і поінформованості всього лише свідомісне інформаційне колажування. Адже «те, що розвиток технологій дозволяє нам користуватися, творити й діставати дедалі більше інформації, не означає, що наш розум здатен усю її засвоїти..., стає дедалі важче розставити пріоритети - відрізнити настирливе від справді важливого...»². Власне, оціночний фактор вибору інформації спрацьовує за принципом, який спостеріг іще в античні часи Пліній Молодший, про що й написав в одному зі своїх листів: «люди, така вже їхня природа, завжди чимось цікавляться: якоюсь голою відомістю купиш навіть тих, хто наставляє вуха усіляким балачкам та побрехенькам» ${ }^{3}$.

Вочевидь, ідеться передовсім про своєрідний словесний контур, який може розширити коло значень культурного концепту твору, а може звузити його до пересічного побутового смислотворення. А отже непростежуваною стає і якість самої мови.

Тобто мова тоді інша, простіша, насправді ж спрощена до рівня «назагал зрозумілої», якою можна підкупити реципієнта, ласого до чужої таємниці, приміром, та й інформативно вона лише розбурхує ниці почуття, а не сприяє духовному вдосконаленню людини. На думку Т. Л. Фрідмана, «тотальне псування мови» це також наслідок «доби переривання». Миттєві повідомлення (SMS), мільйони авторських (радше, приватних, переважно аматорських) блогів, подкасти, відеоконтент спокушають простотою, за якою, може бути інформація конструктивна і деструктивна, правдива і неправдива, потрібна і непотрібна, але, потрапляючи в мережу, вона миттєво поширюється, так само миттєво змінюється, доповнюється, і ніхто вже не зважає на мову чи достовірність, бо така інформація в мережі трансформується у додатковий шум, який згодом перестають помічати. У цьому шумі врешті губиться i саме слово як інтелектуальна одиниця, губиться його смислотворча потуга, бо й смисли тоді дрібніють, коли слово перетворюють лише на інструмент повідомлень на рівні щоденного буденного споживання. I «зримість» самого слова як потужного

\footnotetext{
1 Фрідман, Т. (2008), Світ плаский! Глобалізований світ у ХХІ столітті, Акта, Харків, с. 524.

2 Там само, с. 525.

3 Пліній Молодший (2018), Вибрані листи; пер. Андрій Содомора, Апріорі, Львів, с. 104
} 
інтелектуального потенціалу, що сприяє активному співтворенню з реципієнтом, блякне, затуманюється. Руйнуються якісні зв’язки між словом та його смислом, що призводить до підміни понять. I це тоді, коли якість слова завжди була визначальним чинником якісного смислотворення. Сьогодні ж простежуємо дещо іншу ситуацію, якісним індикатором якої також є слово: збайдужіле суспільство потребує допомоги в осягненні вартісних орієнтирів, а це свідчить про те, що саме занедбання практики активного звернення до софійного (Т. Х.) слова призвело до такого збайдужіння.

Ми звиклися з думкою, що інформація, яку подають нам сучасні 3MI, є правдивою і об'єктивною, але це хибне розуміння інфотворення слова, зорієнтованого передовсім не на глибинне проникнення в нього, а на можливість вільного ковзання лише поверхнею фактів. «Ніколи ще не було такої жахливої диспропорції між Словом і словом» ${ }^{4}$. Сьогодні постала потреба навчитися читати поміж рядків, щоби не опинитись у полоні фальшивих слів і не відчужити практику ЗМІ від її аудиторії, а навпаки - активізувати і1і вплив на смислотворчий процес. «Сприймачі завжди повинні мати вирішальний вплив на майбутнє засобів соціальної комунікації, адже вони своєю волею приймають або відкидають те, що їм запропоновано. Погано тільки, що вони часто недбало ставляться до цієї своєї великої відповідальності, а здебільшого не мають ані нагоди, ані спроможності, щоб якось заперечити творцям медіа-програм або розпочати 3 ними плідний діалог» ${ }^{5}$. А для цього потрібно навчитися правильно розставляти акценти у виборі цінностей і вищих духовних вартостей.

Упродовж століть слово формувало свою справжню суть. Кожен його трактував так, як умів чи вважав за потрібне. А проте тут варто дослухатися до слів Сенеки, який стверджував, що життя таке, яка мова. Зрештою, ці думки можна й перефразувати і стверджувати, що саме мова така, яке й життя. Але як не змінюй, суть залишиться своєрідним підтвердженням того, що слово справді є індикатором і потужною основою усього, що творить/створює людина у процесі осмислення чи переосмислення засадничих основ життя. Зрештою, пригадаймо Біблійну історію творення (Книгу Буття), коли все поставало за словом Божим, і Бог схвалював усе створене, бо «воно було дуже добре», св. Іоан також нагадує про силу Божого Слова, навіть більше. Він говорить, що Богом було Слово. Людина ж у своїй зарозумілості, перечулена здатністю творити - як сам Бог, надміру узалежнила себе від своїх цивілізаційних здобутків.

Відомий український філософ С. Кримський, порівнюючи «антропологічну катастрофу» XX сторіччя, коли «виникла загрозлива колізія між цивілізацією і екзистенцією», та сучасну епоху формування глобальної цивілізації, коли специфікуються глобальні проблеми, говорить, що в нових умовах «цивілізація робить людей богами раніше, ніж вони стають гідними статусу людини». Філософ звертає нашу

\footnotetext{
4 Лось, Й. (2007), Публічистика й тендениії розвитку світу: Навч. посібник для вищих навчальних закладів III-IV рівнів акредитаціï. У 2-x ч.: Ч.1. Видавн. центр Львів. нац. ун-ту імені Івана Франка, Львів, с. 274.

5 Церква і соиіальна комунікація: Найголовніші документи Католицької Церкви про пресу, радіо, телебачення, інтернет та інші медіа (2004), Вид-во Українського Католицького Ун-ту, Львів, c. 17.
} 
увагу на те, що передовсім, за будь-яких обставин, «людина є насамперед істотою, що має внутрішній світ, духовність, свою долю та зверненість до вищих цінностей» 6 .

Якщо так, то людина не може стримувати в собі цю духовну повноту, оскільки $€$ створінням діалогічним, тобто покликана ділитися своїм внутрішнім світом, відкривати його для того, щоб у діалогічному зіткненні відкрити для себе і прийняти світ іншої людини. Це можна потрактувати як діалогічний момент звільнення і водночас взаємозбагачення. Слово ж у цьому діалозі є цілістю, яку генерує людський розум, думка. В такому діалозі людина дозріває духовно, піднімається усіма щаблями діалогічного пізнання світу (про що автор цісї статті - у своїй монографії) через задіяння до довершеного творчого комунікативного процесу (комунікативної піраміди), який засвідчує наш духовний розвиток і на рівні віддзеркалення думок чи продуктивної сукупності «атомів» монологів може мати таке схематичне вираження: а) людина - особа; б) людина - інша людина; в) людина -суспільство; г) людина - Бог. В ідеалі таку схему можна вважати моделлю морального вдосконалення людини, проекцією її в майбутнє і водночас комунікативним, а передовсім - діалогічним, процесом творення особистості. Це орієнтує людину, яка завжди стоїть перед вибором між своїм осучасненням, вживанням в епоху й вартостями (універсальними), на здобуття самоцінності, справжності і так би мовити духовного розширення.

Маршалл Маклуен ще у 1962 році, характеризуючи «електричну добу», вказав на позитивний процес «розширення людини» з огляду на цивілізаційні здобутки людства. Ознакою цього розширення він вважав той факт, що «ми дедалі частіше переносимо увагу зі змісту повідомлення на вивчення тотального ефекту», адже ефект, на його думку, «містить в собі всю ситуацію цілком, а не просто якийсь один рівень руху інформації» ${ }^{8}$. Щоправда така цілість свідчить радше про резонування інформації як ефекту від її багатозначного смислового тлумачення, що, звісно, може підсилити діалогічність герменевтичних інтеракцій, але не дасть діалогу розвинутися власне у царині змістотворення, залишаючи співбесідникам лише поле для пустих розмов. I якщо людина може стати заручником медіа продукту, то заручником смислотворчого діалогу стати набагато важче.

Не випадково Андрій Содомора, відомий знавець творчості античних авторів, заакцентував: «Не здобутки техніки, а вага Слова в суспільстві визначає міру його цивілізованості». І навчити викристалізовувати цілюще слово з того набору запрограмованих фраз, які нас зомбують до сліпого наслідування нав’язливих стереоти-

${ }^{6}$ Кримський, С. (2003), Заклики духовності XXI століття: [3 циклу щоріч. пам'ят. лекцій ім. А. Оленської-Петришин, 2002 р.], Вид. дім «КМ Академія», Київ, с. 5.

7 Хоменко, Т. (2008), Проповідництво і сучасна публіцистика, ПАІС, Львів, 136 с. (Про це також у 2000 році писала О. Федик у книзі «Мова як духовний адекват світу (дійсності)» (Львів, Місіонер, 300 с.). Самооцінити свої вчинки і думки, проникнути у власну сутність, відкрити для себе гармонію світу, можна, на думку О. Федик, лише визнаючи високе призначення слова. О. Федик вважала, що, відчуваючи і розуміючи вартість мови, людина стає духовно багатшою, а отже побільшує свій простір духовності, продовжує його в часі і підтримує поліфункціональне здійснення мовних актів).

8 Маклуен, М. (2003), Понимание медиа: Внешние расширения человека /e-reading.club. URL: https://www.e-reading.life/book.php?book $=102820$

9 Содомора, А. (2000), «Не здобутки техніки, а вага Слова в суспільстві визначає міру його цивілізованості», День, с. 18. 
пів, як не парадоксально, мають ті, хто опанував слово - художнє, публіцистичне, а чи медійне.

Тут може спрацювати «закон про незнищенність духової енергії» ${ }^{10}$ слова, як про це С. Сверстюк, який у слові намагається не просто відобразити світ, перелічивши факти, не просто вказати на проблему чи вихід із неї, а, передусім, накреслити людям дорогу до Бога, яка обов'язково пролягає через правду та істину. Окрім того, Є. Сверстюк стверджує, що саме у творчості також криється глибоке джерело любові, яку туди заклав їі автор ще десятки, а то й сотні років тому. Бо й «Шевченка люблять не інакше, як у відповідь на його велику любов, нечувану силу любови i доброти» ${ }^{11}$. Любов у відповідь, це, власне, вже початок діалогу, який акцентує увагу на діалогічності людського життя, а полягає ця діалогічність в налаштованості на діалог, в очікуванні діалогу, готовності до діалогу та в своєрідному вичікуванні слушної нагоди вступити в діалог. Адже в діалозі людина доростає до важливого для неї розуміння того, ким вона є в цьому житті. Що як не слово передовсім допомагає їй це зрозуміти? І сьогодні, коли нашому «зовнішньому розширенню» сприяє, а навіть спонукає до нього, бажання бути поінформованим, то варто подбати і про приватну інформаційну безпеку, щоб убезпечитись від маніпулювання нашою цікавістю. А в світі зловорожості не випадково навіть нові терміни в журналістикознавчому обігу підкреслюють те, як далеко в творчості ми відійшли від обов'язку відповідальності за слово, того деонтологічного принципу, який вберігає не від «кризовості» в комунікації, «мови ворожнечі» та інших сучасних і вже, на жаль, усталених штампів, а від того, що насправді вони окреслюють. Спираючись на цю думку, можна припустити, що справжній талант - це вміння будь-якого автора закласти у свій твір насамперед любов як своєрідне послання читачам, глядачам чи слухачам. Тобто, пишучи з любов'ю, автор мусить любити тих, кому адресує свої твори, і вчити їх любові. Актуальним, резонансним є лише той твір, автор якого, окрім негараздів і нещасть, бачить не лише їхніх призвідників, не фотографічно відтворює подію, але й щиро намагається (справді прагне) допомогти, розрадити, підтримати тих, хто потерпає від свавілля і несправедливості, і робить це не для піару і без пафосного набору сльозливих штампів. Це перетворює монологічний пафос на цілісний животрепетний духовний діалог з аудиторією, в якому співіснують всі учасники, в якому усі іншості мають ціннісну вагу, є самоцінними і цікавими та потрібними одне одному.

Але треба розуміти ще й те, що в цьому діалозі кожен «інший»- це й світ іншості, який $є$ реальністю, що їі формують соціальні інститути, досвід спілкування, читання, а також 3МI, з усіма сучасними можливостями формування думки та маніпуляцією свідомістю. У передмові до збірки поезій італійського поета К. Калабро О. Пахльовська докладно аналізує поезію цього непересічного митця, але водночас через герменевтику самого поетичного тексту розширює горизонти нашого розуміння логічного і дуже плідного союзу любові і слова, а також трансформації цієї спілки сьогодні у трагедію «остаточного слова», яка розгортається на тлі містерії сучасного життя, відірваного від справжньої любові як благодаті Божої і від Слова як Божої

\footnotetext{
${ }^{10}$ Сверстюк, С. (1999), «Іван Котляревський сміється», На святі надій. Вибране, URL: http:// ukrlife.org/main/sverstuk/kotlar.htm

${ }^{11}$ Сверстюк, С. (2004) «Любов, яку ми успадкували», На хвилях «Свободи. Короткі есеї, ВМА «Терен», Луцьк, с. 51.
} 
даності, коли відбувається «боротьба з девальвацією любові і слова, двох універсальних стихій людського буття. В добу, коли все стає подібним до instant-істини «швидкорозчинної» істини, коли можна навіть шекспірівське «бути чи не бути» «to be or not to be» написати на мобільнику як « 2 be or not 2 be» ${ }^{12}$. Оце світоглядне вагання, і спрощення (умовність) слова знецінюють його пасіонарність. Але ж знаємо, що енергію слова розуміли віддавна. Найвідомішим, сьогодні - хрестоматійним, $\epsilon$ наказ Володимира Мономаха: «Не лютувати словом». А найбільшої , мабуть, смислової ваги надав слову Т. Шевченко. У його поезії воно «добре», «святеє», «Боже», «щире», «ласкаве», «розумне», «тихе», «тихо-сумне», «богобоязливе», «великеє», «веселеє», «слово правди і любови», «лихе», «найкращеє», «мудре», «голос» - як синонім до «слова» у діаді «verbum» / «vox» і як сама дія. Наприклад, ця духовна енергія-дія слова буквально унаочнюється в Шевченкових, генеруючи цю енергію, формулах: «Я на сторожі коло них поставлю слово»; «Щоб слово пламенем взялось»; «І на Україні святилось / Те слово, Божеє кадило, / Кадило істини. Амінь»; «І тихим, добрим, кротким словом / Благовістив їм слово нове, / Любов, і кротость, і добро»; «Німим отверзуться уста / Прорветься слово, як вода»; «Орю / Свій переліг - убогу ниву! / Та сію слово. Добрі жнива / Колись-то будуть»; «Своїм святим огненним словом / Ти дух святий свій пронесла» ${ }^{13}$ та ін.

Услід за Шевченком і Франко у поезії «Якби ти знав як много важить слово...» у дихотомічному співставленні показує нам слова- індикатори нашої людяності (Одно сердечне, теплеє слівце! / Глибокі рани серия як чудово / Вигоює - якби ти знав оце! / Ти, певно б, поуз болю і розпуки, / Заціпивши уста, безмовно не минав, / Ти сіяв би слова потіхи і принуки, / Мов теплий дощ на спраглі ниви й луки) та егоїстичної безвідповідальної експлуатації слова (Якби ти знав, які глибокі чинить рани / Одно сердите, згірднеє слівце, / Як чисті душі кривить, і поганить, / I троїть на весь вік...).

У бажанні збагнути слово як духовну силу, що дає змогу людині реалізувати себе у творчому осягненні світу, і Шевченко, і Франко усвідомили слово як потугу, яку людина має скеровувати на вдосконалення світу задля збереження світу і себе у ньому. Але й наодинці зі світом людина не зможе зреалізуватись, їй потрібно проговорити свої ідеї, звіритись комусь, бо тільки із зіткнення ідей вимовлених, народжується врешті істина, бо в діалозі ми відкриваємося один до одного. Ще античні хотіли почути людину, щоб її побачити, вочевидь, очима серця.

Результати і перспективи подальших досліджень. Перспективи наукової розвідки такої теми полягають у двоцентровості дослідження: через призму досвіду словорозуміння минулого ми екстраполюємо проблему на процес сучасного розуміння ваги слова в комунікативному процесі; на прикладі творчості видатних персоналій світової та української культури відстежуємо вплив слова на формотворення духовного простору людства (в глобальному сенсі) і національного духовного комунікативного простору (з огляду на діалогічну природу самої людини, яка готова до

${ }_{12}$ Пахльовська, О. (2009), «Поезія - «прихована маса Всесвіту» : передм. до кн. Калабро, К. Я не скажу тобі, що це любов, Літопис, Львів, с. 27, 38.

${ }^{13}$ Конкорданиія поетичних творів Тараса Шевченка (2001), University of Alberta. - New York: Shevchenko Scientific Societi; Edmonton; Toronto : Canadian inst. of Ukrain. studies press, T. 1, 774 c. 
людинотворення в широкому розумінні цього явища, починаючи від аутокомунікування до виходу на інтелектуальний полілог через діалогічне пізнання істини).

Висновки.

У комунікативному простір сучасності сьогодні гостро відчувається дефіцит аксіологічного наповнення мови, що зумовлено перевиробництвом інформації, яка не завжди сприяє духовному росту людини. Через смислову підміну вартості слова як інтелектуальної потуги світоглядності мислення деформується парадигма морально-етичного дозрівання людини і діалогічні рівні світоосягнення. Діалог, в якому народжується істина, втрачає свої інтелектуальні позиції. Натомість світова балаканина, щодо якої застерігали біблійні автори, міцніше утверджується в світі інформації, тому критичне мислення не визріває серед постійної навали інформаційного негативізму, а осмислення цієї проблеми в «добу переривання» сприяє лише «зовнішньому розширенню» людини, яка наповнюється інформацією, що не завжди є знанням. Духовне ж «розширення» здійснюється в інтерактивному практикуванні засвоєння тих філософських істин, які якісно наснажують мову комунікативних актів, починаючи від приватного діалогу, і доходять до діалогу, скерованого в майбутнє, індикатором цивілізованості, якості якого, власне, як колись і тепер, буде пасіонарна напруга Слова і деонтологічний принцип обов'язку відповідальності за втручання в його смислове поле.

\section{СПИСОК ЛІТЕРАТУРИ}

1. Конкорданція поетичних творів Tараса Шевченка $=$ A Concordance to the Poetic Works of Taras Shevchenko (2001) / ред.-упоряд. О. С. Ільницькмй, Ю. Гавриш; University of Alberta. - New York : Shevchenko Scientific Societi; Edmonton; Toronto : Canadian inst. of Ukrain. studies press, T. 1, $774 \mathrm{c}$.

2. Кримський, С. (2003), Заклики духовності XXI столітmя: [3 циклу щоріч. пам'ят. лекцій ім. А. Оленської-Петришин, 2002 р.], Вид. дім «КМ Академія», Київ, 32 с.

3. Лось, Й. (2007), Публічистика й тендениії розвитку світу [Текст]: навч. посіб. у 2-x ч. Ч.1., Вид. центр Львів. нац. ун-ту імені Івана Франка, Львів, 376 с.

4. Маклуен, М. (2003), Понимание медиа: Внешние расширения человека / e-reading. club, URL: https://www.e-reading.life/book.php?book=102820

5. Пахльовська, О. (2009), «Поезія - «прихована маса Всесвіту» : передм. до кн. Калабро, К. (2009), Я не скажу тобі, що це любов, Літопис, Львів, с. 15-34.

6. Пліній Молодший (2018), Вибрані листи; пер. Андрій Содомора, Апріорі, Львів, $184 \mathrm{c.}$

7. Сверстюк, Є. (1999), «Іван Котляревський сміється», На святі надій. Вибране. URL: http://ukrlife.org/main/sverstuk/kotlar.htm

8. Сверстюк, С.(2004), «Любов, яку ми успадкували», На хвилях «Свободи». Короткі есеї, ВМА «Терен», Луцьк, 312 с.

9. Содомора, А. (2000), «Не здобутки техніки, а вага Слова в суспільстві визначає міру його цивілізованості», День, 8 груд., с. 18.

10. Федик, О. (2000), Мова як духовний адекват світу (дійсності), Місіонер, Львів, $300 \mathrm{c}$.

11. Фрідман, Т. (2008), Світ плаский! Глобалізований світ у ХХІ столітті, Акта, Харків, 676 с. 
12. Хоменко, Т. (2008), Проповідництво і сучасна публіиистика, ПАІС, Львів, 136 с.

13. Церква і соціальна комунікація: Найголовніші документи Католицької Церкви про пресу, радіо, телебачення, інтернет та інші медіа (2004), Вид-во Українського Католицького Ун-ту, Львів, 440 с.

\section{REFERENCES}

1. Konkordantsiia poetychnykh tvoriv Tarasa Shevchenka $=A$ Concordance to the Poetic Works of Taras Shevchenko (2001) / red.-uporiad. O. S. Ilnytskmi, Yu. Havrysh; University of Alberta. - New York : Shevchenko Scientific Societi; Edmonton; Toronto : Canadian inst. of Ukrain. studies press, T. 1, $774 \mathrm{s.}$

2. Krymskyi, S. (2003) Zaklyky dukhovnosti KhKhI stolittia: [Z tsyklu shchorich. pamiat. lektsii im. A. Olenskoi-Petryshyn, 2002 r.], Vyd. dim «KM Akademiia», Kyiv, 32 s.

3. Los, Y. (2007), Publitsystyka y tendentsii rozvytku svitu [Tekst]: navch. posib. u 2-kh ch. Ch.1., Vyd. tsentr Lviv. nats. un-tu imeni Ivana Franka, Lviv, 376 s.

4. Makluen, M. (2003), Ponymanye medya: Vneshnye rasshyrenyia cheloveka / e-reading. club, URL: https://www.e-reading.life/book.php?book=102820

5. Pakhlovska, O. (2009), «Poeziia - «prykhovana masa Vsesvitu» : peredm. do kn. Kalabro, K. (2009), Ya ne skazhu tobi, shcho tse liubov, Litopys, Lviv, s. 15-34.

6. Plinii Molodshyi (2018). Vybrani lysty; per. Andrii Sodomora, Apriori, Lviv, 184 s.

7. Sverstiuk, Ye. (1999), «Ivan Kotliarevskyi smiietsia», Na sviati nadii. Vybrane. URL: http://ukrlife.org/main/sverstuk/kotlar.htm

8. Sverstiuk, Ye.(2004), «Liubov, yaku my uspadkuvaly», Na khvyliakh «Svobody». Korotki esei, VMA «Teren», Lutsk, 312 s.

9. Sodomora, A. (2000), «Ne zdobutky tekhniky, a vaha Slova v suspilstvi vyznachaie miru yoho tsyvilizovanosti», Den, 8 hrud., s. 18.

10. Fedyk, O. (2000), Mova yak dukhovnyi adekvat svitu (diisnosti), Misioner, Lviv, 300 s.

11. Fridman, T. (2008), Svit plaskyi! Hlobalizovanyi svit u XXI stolitti, Akta, Kharkiv, 676 s.

12. Khomenko, T. (2008), Propovdnytstvo i suchasna publitsystyka, PAIS, Lviv, $136 \mathrm{s.}$

13. Tserkva i sotsialna komunikatsiia: Naiholovnishi dokumenty Katolytskoi Tserkvy pro presu, radio, telebachennia, internet ta inshi media (2004), Vyd-vo Ukrainskoho Katolytskoho Universytetu,Lviv, $440 \mathrm{~s}$. 


\title{
A WORD AS AN INDICATOR OF COMMUNICATION IN THE SPIRITUAL DIALOGUE: DEONTOLOGICAL ASPECT
}

\author{
Tetiana Khomenko \\ Ivan Franko National University of Lviv, \\ Generala Chuprynky Str. 49, 79044, Lviv, Ukraine \\ e-mail:homenko.tet@gmail.com \\ https://orcid.org/0000-0003-2917-3469
}

The article deals with the problem of contextual change of meaning of the Word as dominant in the cultural building, quality of communication, building of meaning and serious intellectual unit of world's paradigmatic thinking. It has been noted in particular that modern informational space is oriented at the newest "daily shedule", according to which, on the one side, the information is delivered today for today; and on the other side, the principle "only bad news are good news" is being used. Deontological principle of the responsibility for the dialogical content of the sophisticated word is being ignored on the regular basis.

Moral degradation more and more invades the healthy part of the society.

In today's world human targets are changed, pragmatism displaces spirituality.

The variety of media sources completes their mission to secure the truth of the word, and this mission is often being interpreted from the position of moral degradation. Meanwhile, this position is being covered by fictitious truth and generosity (the evidence to this was well represented at recent elections). The changes to the word content became really evident. This fact points at the need for reaction against modern informational and propagandistic technologies. This reaction relies in the need for returning the real truth to the word in order to prevent future manipulations.

Informational space can be defined as completed with factual data, in comparison to the communicative one, which is filled with interpretation. Interpretation requires constant checkups, which are strengthened by constructive dialogue.

Key words: word, spirituality, moral values, dialogue, qualitative communication, responsibility. 